\title{
MANAJEMEN EMOSI PADA PASIEN ANAK RAWAT INAP (HOSPITALIZED CHILDREN) MELALUI EKSPRESI TULIS \& GAMBAR
}

\author{
Dian Sari Utami \\ Universitas Islam Indonesia \\ Amitya Kumara \\ Universitas Gadjah Mada
}

\begin{abstract}
Children are very vulnerable with their bodies, especially when they are ifl. This condition is so uncomfiortable for childran to get ill, moreover when they have to be hos pitalized. Children usually have chronic illness and should be hospitalized for long time. This condition would affect not only their bodies, but their mind's and emotions. Hospitalized would make children getting stress or distress and need to cope. One way to cope is managing their emotions through writing and drawing as a method to express their emotions. This study used the book as a media b express their emotion called "Pelangl Hatiku".

The quailative method using in this study is case study. The participants who involved in this case study were 3 children of 8-12 years-oid from 2 general hospilals in Yogyakarta. They were interviewed and observed regarding to their steps of managing emotions using "Peiangi Hatiku".

It was found that managing emotions consisted of four steps, they are spontanelusly, events thinking deeply, involving or withdrawai from emotions reflectivgiy, reducing negative emotions by increasing positive emotions. Furthermore, the Emotionai Detections Scale from prelest and posttest showed the score decreasing in which means that there was increasing in their abilities to manage their emotions.
\end{abstract}

Keywords: emotional management, writing, drawing

\section{Pengantar}

Setiap penyakit, betapapun ringannya, seperti flu, sakit perut, kepala pusing, dirasakan oieh seseorang sebagai suatu gangguan dalam kehidupan sehari-hari. Oleh sebab itu penyakit tidak disambut baik. Apalagl jika seseorang harus dirawat d rumah sakit, maka emosi negatif akan banyak muncul. Jika anak-anak yang mengalami kondisi rawat inap dalam waktu yang cukup lama, maka kondisi fissik tidak lagi menjadi faktor utarna bagi kesembuhan, namun diperlukan keseimbangan psikis dan spirituai daiam menghadapi kondisinya selama dirawat inap.

Data rekam medik tahun 2002 di Rumah Sakit Umum Pusat Dr Sardjito menunjukkan bahwa jumlah pasien anak rawat inap yang belurn kembaii cenderung meningkat setiap bulannya. Tiga jenis penyakit dari yang tertinggi yang diderita pasien anak rawat inap selama tahun 2002 adaiah dengue fever $(18 \%)$, diarrea \& gastroenterilis of persued infectious origin sebesar (16\%), dan acute nasopharyngitis atau commond coid (12\%). Berdasar data Ini tampak bahwa commond cold menempatl 
peringkat ketiga dari 10 besar penyakit rawat inap. Padahal commono colo bukan merupakan indikasi untuk rawat inap. Kemungkinan diagnosa commond cold bukan merupakan diagnosa utama, hanya sebagai penyakit penyerta, dirawat karena demam dan orangtua pasien fobia dengan demam berdarah dengue (Rekam Medis, 2003).

Selain jenis penyakit, yang juga menyebabkan terjadinya perubahan distres pad a anak adalah kondisi anak yang sedang dirawat inap. Ketka observasi dilakukan pada anak-anak yang dirawat inap, terutama di rumah sakit umım, tampak bahwa mereka mengalami kebosanan, merasa keseplan, merasa tidak berdaya, tidak tahu apa yang harus dilakukan, mudah marah, merasa takut, cemas, dan ada yang sering menangis.

Pasien yang dirawat di rumah sakit biasanya mengalami kecemasan karena memikirkan gangguan atau penyakitnya, merasa bingung dan cemas mengenal harapan hasil perawatan serta risau dengan peran yang ditinggalkan. Pasien harus melakukan penyesuaian terhadap situasi baru yang sukar. Rumah sakit kurang dapat menenangkan pasien cemas, bahkan memperburuk kondisi tersebut (Mason, dkk. 1965). Pasien rumah sakit sering menunjukkan berbagai simtom psikologis, terutama kecemasan dan depresi (Pennebaker, dkk. 1977). Pasien bahkan merasa tidak berdaya (Taylor, 1995).

Pada pasien dengan penyakit akut, ada fase pertama ketika aktivitas dalam kehidupan mereka menjadi kacau, lebihlebih jika seseorang mengalami penyakit kronis. Setelah didiagnosis menderita penyakit kronis, maka seseorang akan mengalami keadaan krisis karena ketidakseimbangan fisik, sosial, dan psikologis (Moos, 1977). Hal ini terjadi karena individu tersebut akan menghadapi kenyataan bahwa cara-cara yang selama in digunakan untuk menghadapi masalah yang muncul tidak berfungsi, akibatnya akan terjadi perasaan "disorganisasi", kecemasan, takut, dan emosi lain (Taylor \& Aspinwall, 1990).

Berdasar penjelasan yang dikemukakan dl atas terlihat bahwa rasa sakit. yang diderita seseorang, baik penyakit akut maupun kronis akan mengakibatkan perubahan fisik, sosial, maupun psikologis. Apalagi bagi pasien yang dirawat di rumah sakit, individu tersebut.juga harus melakukan penyesuaian terhadap situasi baru. Hal-hal inilah yang sering memunculkan emosi negatif.

Anak-anak yang terbiasa melakukan banyak aktivitas ketika sehat akan cenderung mengalami stres ketika dirawat inap. Mereka akan memprotes dan bersikap melawan ketika mendapatkan perlakuan medis yang menuntut mereka untuk mengurangi gerakan can akitivitas (Smith \& Autman, 1985). Walaupun demikian, hal yang paling rentan menjadi sumber stres pada anak-anak yang dirawat inap adalah keterpisahan dari orang tua mereka (Sarafino, 1998).

Sarafino (1998) menjelaskan bahwa orang dari segala usia memiliki kesulitan dalam melakukan coping ketika mendapatkan perawatan inap dan perlakuan medis. Hurlock (1996) menjelaskan bahwa pola emosi pada masa kanak-kanak akhir berbeda dari pola emosi pada masa awalnya dalam dua hal, yaitu jenis situasi yang membangkitkan emosi dan bentuk ungkapannya. Perubahan tersebut merupakan hasil bertambahnya pengalaman dan proses belajar daripada proses pematangan itu sendiri. Menurut Campbell (1996), untuk mencapai kesuksesan akademik anak-anak membutuhkan sarana penyaluran emosi yang positif. Untuk itu sebaiknya sedini mungkin anak-anak dilatih untuk dapat memanaje emosinya. Meski tidak mudah, tetapi anak pertu dilatih agar bisa mengekspresikan perasaanperasaannya dengan cara yang positif, yang tidak merugikan dirinya dan juga orang lain.

Pennebaker (1990) dalam penelitiannya mengungkapkan bahwa nilai utama dari menulis adalah kemampuannya mengurangi pengekangan. Peristiwaperistiwa mengganggu yang dituliskan akan memberikan pemahaman baru tentang peristiwa emosional itu sendiri. Menuliskan pengalaman-pengalaman yang 
mengganggu secara psikologis, dan mungkin secara fisik, cukup menguntungkan. Melalui menulis ini, anak akan belajar untuk mengekspresikan omosiemosi yang dirasakannya, terutama emosiemosi negatif sebagal manifestasi dari perasaan distres karena sakit fislk yang dialami apalagi ketika anak juga harus dirawat inapdi rumah sakit.

Manajemen emosi pada anak memerlukan media yang mampı membantu mengungkapkan dan mengontrol emosinya agar tercapai kondisi tubuh yang seimbang serta dapat menampung katarsis fisik dan mental anak karena ekspresi-ekspresi emosi mereka yang ditekan. Sakah satu media tersebut adalah penggunaan buku "Pelangi Hatiku" sebagai sarana melakukan manajemen emosi pada anak yang mengaiami trauma. Melalui buku "Pelangi Hatiku" anak akan mengekspresikan emosi mereka dalam bentuk apresiasi seni melalui tulisan dan gambar sebagai upaya untuk mengenal dan mengelola emos| mereka.

\section{Pertanyaan Penelitian}

Berdasarkan penjelasan di atas, maka penelitian hini bertujuan untuk mengetahui bagaimana tahapan manajemen emosi pada pasien anak-anak yang dirawak inap melaiui penggunaan buku "Pelangi Hatiku"?

\section{Tinjauan Pustaka}

\section{Konsep Emosi}

Emosi diartikan juga sebagai suatu kondisi "kesiapan aksi" yang terjadi pada seseorang yang mengawall pengendalian perilaku emosional (Markham, 1994). Terdapat dua teori yang menerangkan emosi, yaitu:

1. Tecri yang menyatakan bahwa emosi akan muncul sebagai reaksi adanya harapan kognitif. Aktivitas sistem saraf otonomik merupakan reaksi emosi yang muncul. Teori ini dikembangkan oleh Scachter dan Singer (Ekman, dkk., 1980).

2. Teori yang menyatakan bahwa emosi merupakan perubahan sistem respon yang berbeda-beda untuk tiap-tiap emosi. Teori James dan Lange menyatakan bahwa emosi akan muncul apabila terjadi perubahan tubuh (Zajonc, dkk., 1989). Emosi adalah sumber energi yang membangkitkan dan memobilisasi individu. Emosi marah menggerakkan individu untuk agresif, takut menggerakkan individu untuk iari.

Kata emosi (emotion) berasal dari kata motion, yang berarti gerakan. Emosi adalah gejala manusia yang mengantar manusia untuk bergerak. Manusia bergerak berdasarkan pikiran. Segala tingkah lakunya merujuk pada pemahamannya (Goleman, 1995). Ditambahkan pula bahwa emosi merupakan kondisi tergugah individu yang berwujud pengalaman akan perasan tegang (foeling of tension) maupun rasa terangsang (feoling of excitiment) (John dkk. dalam Ananda 2000). Kondisi tergugah ini akan menurun ketika individu mampu memuaskan kebutuhan-kebutuhannya.

Coleman (Rakhmat, 1996) mengemukakan tiga fungsi gerakan emosi manusia, yaitu :

1. Emosi adaiah pembawa informasi.

2. Emosi berguna daiam komunikasi interpersonal.

3. Emosi adalah sumber informasi.

Kemampuan untuk bereaksi secara emosional sudah ada sejak bayl yang baru lahir. Gejala pertama perilaku emosional adalah keterangsangan umum yang sangat dipenganuhi oleh proses belajar emosi anak yang berasal dari stimulasi lingkungan di mana dia tinggal. Hal ini akan memuncukkan perubahan-perubahan emosi. Ada beberapa kondisi yang mempengaruhi perkembangan emosi anak, yaitu faktor pematangan (maturation) dan faktor belajar.

Penelitian akhlr Cooper dan Sawaf (2000) menambahkan makna emosi secara konvensional kepada makna emosi secara high-porformance. Emosi dalam makna high-performance dapat diartikan sebagai sumber energi, semangat manusla yang paling kuat, memacu semangat belajar, memperjelas, mendorong atau mempercepat penalaran, memacu kreativitas dan inovasi, dan memotivasi. 
Studi-studi saat ini juga mengungkapkan bahwa emosi penting sebagai "energi pengaktif" untuk nilai-nilai etika, misalnya kepercayaan, integritas, keuletan, dan kredibilitas. Ditambahkan pula oleh Cooper dan Sawaf bahwa emoș memberi makna pada situasi-situasi dalam hidup. Emosi bukanlah pengganggu atau pengacau bahkan merupakan sesuatu yang paling penting dalam keberadaan individu. Emosi juga mendorong seseorang untuk menjawab pertanyaan-pertanyaan yang mendalam dan paling penting mengenai keberadaan seseorang.

Berdasar teori-teori emosi yang telah dikemukakan, maka dapat disimpulkan bahwa emosi adalah suatu bentuk perasaan yang bersifat mendalam yang mempengaruhi individu dalam berpikir dan berperilaku. Pada keseimbangan emosi yang ideal, timbangan harus condong ke arah emosi yang menyenangkan sehingga emosi itu mempunyai kekuatan melawan kerusakan psikologis yang ditimbutkan oleh dominasi emosi yang tidak menyenangkan.

Pasien yang dirawat di rumah sakit blasanya mengalami kecemasan karena memikirkan gangguan atau penyakitnya, merasa bingung dan cemas mengenaí harapan hasil perawatan serta risau dengan peran yang ditinggalkan. Pasien harus melakukan penyesuaian terhadap situasi baru yang sukar. Rumah sakit kurang dapat menenangkan pasien cemas, bahkan memperburuk kondisi tersebut (Mason, dkk., 1965). Pasien rumah sakit sering menunjukkan berbagai simtom psikologik, terutama kecemasan dan depresi (Pennebaker, dkk., 1977). Pasien bahkan merasa tidak berdaya (Taylor, 1995).

Pada pasien dengan penyakit akut, ada fase pertama ketika aktivilas datam kehidupan mereka menjadi kacau. Apalagi jika seseorang mengalami penyakit kronis. Setelah seseorang didiagnosis menderita penyakit kronls, maka akan terjadi keadaan krlsis karena ketidakseimbangan fisik, sosial, dan psikologik (Moos, 1977). Hal ini terjadi karena individu tersebut akan menghadapi kenyataan bahwa cara-cara yang selama ini digunakan untuk menghadapi masalah yang muncul tidak berfungsi. Akibatnya akan terjadi perasaan "disorganisasi", kecemasan, takut, dan emosi lain (Taylor \& Aspinwall, 1990).

Reaksi emosi anak terhadap keadaan dan penyakitnya sedikit banyak ditentukan oleh tingkat perkembangan kognitif dan emosinya. Pemahaman mereka tentang penyakit dan pengobatan akan terlihat pada respon-respon emosionatnya. Sikap orangtua terhadap penyakit dan pengobatan juga akan bepengaruh besar. Penelitian yang difakukan oleh Brewster (Eiser, 1984) pada anak-anak yang dirawat inap of rumah sakit menunjukkan bahwa tingkat perkembangan kognitif anak akan mempengaruhi persepsinya terhadap penyakit, dan selanjutnya pada seberapa jauh anak dapat menerima tIndakan pemeriksaan, pengobatan serta sikap terhadap para petugas kesehatan. Hasil penelitian tersebut adalah sebagai berikut:

Tabel 1.

Hasil Penelltan Brewster

\begin{tabular}{|c|c|c|}
\hline Umur & $\begin{array}{c}\text { Pendapat Anak tentang } \\
\text { Penyakit }\end{array}$ & $\begin{array}{l}\text { Pengertian tentang Tindakan } \\
\text { Pemerksaan dan Pengobatan serta } \\
\text { Sikap terhadap Dokter / Perawat }\end{array}$ \\
\hline $5-7$ tahun & Disebabkan ulah manusia & $\begin{array}{l}\text { Pemerlksaan \& pengobatan adalah } \\
\text { hukuman, dokter bemiat menyakitiku }\end{array}$ \\
\hline $7-11$ tahun & $\begin{array}{l}\text { Disebabkan bibit } \\
\text { penyakit }\end{array}$ & $\begin{array}{l}\text { Tindakan telah dapat dipahami. Dokter } \\
\text { lidak bermaksud menyakiti, tetapi mereka } \\
\text { kurang be rem pati dan tidak peduli }\end{array}$ \\
\hline 11 tahun ke atas & $\begin{array}{l}\text { Disebabkan kerentanan } \\
\text { atau kelemahan fisik }\end{array}$ & $\begin{array}{l}\text { Tindakan dan maksud dokter tetah } \\
\text { dipahami secara tepat. Tetapi mereka } \\
\text { tidak tahu seberapa banyak itu } \\
\text { membuatku teruka }\end{array}$ \\
\hline
\end{tabular}




\section{Manajemen Emosi}

Kata "manajemen" memiliki kesamaan makna dengan kata "mengelola" yang berarti mengendalikan. Kata "pengelolaan" diartikan sebagai proses melakukan kegiatan tertentu dengan menggerakkan tenaga orang lain (Tm Penyusun Kamus Pusat Pembinaan dan Pengembangan Bahasa, 1990). Sedangkan dalam Oxford Advanced Learner's Dictionary (Hornby, 1974) kata manage dan regulate memiliki kesamaan makna, yaitu mengontrol. Sedangkan Goleman (1995) menyatakan bahwa mengelola emosi disebut juga selfregulating, yaitu kemampuan mengelola emosi berkaitan dengan cara seseorang mengakomodasi emosi yang dirasakannya. Orang-orang yang rendah kemampuannya akan terus menerus bertarung melawan perasaan murung, sementara orang yang mempunyai kemampuan akomodasi perasaan yang tinggi akan dapat bangkit kembali dari kemerosotan dengan jauh lebih cepat.

Manajemen emosi yang dilakukan oleh seorang anak akan dipengaruhi oleh perkembangan bahasanya. Anak yang sudah mampu menggunakan bahasa dengan baik, akan memiliki kemampuan untuk mengekspresikan apa yang mereka rasakan dan melakukan strategi coping (Sarafino, 1998). Manajemen emosi atau manage emotion merupakan salah satu pengarahan reflektif emosi untuk mempromosikan pengembangan emosi dan Intelek sebagai salah satu tahapan dalam mencapai kecerdasan emosi (Mayer \& Salovey, 1997). Penjelasan ini merupakan revisi dari tulisan Salovey yang dikaji dalam buku Goleman yang berjudul Emotional Intelligence (Prawitasari, 1998). Lebih jelasnya Mayer dan Salovey (Salovey \& Sluyter, 1997) mengemukakan empat tahapan ketrampilan emosi menuju kecerdasan emosi dan masing-masing taha pan terdiri atas em pat hal, yaitu :

1. Persepsi, penillaian, dan ekspresi emosi. Tahapan ini membutuhkan empat kemampuan, antara lain :

a. Kemampuan untuk mengenal emosi secara fisik, rasa, dan pikir. b. Kemampuan untuk mengenal emosi pada orang lain, desain, karya seni meialui bahasa, bunyi, penampilan, dan perilaku.

c. Kemampuan untuk mengungkapkan emosi secara tepat, dan mengungkapkan kebutuhan sehubungan dengan rasa-rasa tersebut.

d. Kemampuan untuk membedakan ungkapan rasa antara tepat dan taktepat,jujurversus takjujur.

2 Fasilltasi emosi untuk berpikir, terdiri atas:

a Emosi memberikan prioritas pada pikiran dengan mengarahkan perhatian pada informasi penting.

b. Emosi cukup gamblang dan tersedia sehingga emosi tersebut dapat digunakan sebagai bantuan untuk menilai dan ingatan yang berhubungan dengan rasa.

c. Perubahan emosi mengubah perspektif individu dari optimis menjadi pesimis, mendorong untuk mempertimbangkan berbagai pandangan.

d. Keadaan emosi mendorong adanya pembedaan pendekatan khusus dalam pemecahan masalah, misalnya ketika kebahaglaan memberikan fasilitas untuk penalaran induktif dan kreativitas.

3. Pengertian dan penguraian emosi; penggunaan pengetahuan emosi, terdiri atas:

a. Kemampuan untuk memberikan label emosi dan mengenal hubungan antara berbagai kata dan emosi itu sendiri, misalinya hubungan antara menyukai dan mencintai.

b. Kemampuan untuk mengartikan bahwa emosi berkaitan dengan hubungan, misalnya kesedihan sering menyerfai kehilangan.

c. Kemampuan untuk mengerti rasa yang kompleks: rasa cinta bersamaan dengan benci ; atau campuran, seperti takjub adalah kombinasi takut dan terkejut.

d. Kemampuan untuk mengenal 
adanya perpindahan di antara emosi, seperti adanya perpindahan dari marah ke puas atau marah ke malu.

4. Pengarahan reflektif emosi untuk mempromosikan pengembangan emosi dan intelek yang terdiri atas:

a. Kemampuan untuk tetap terbuka terhadap perasaan, baik itu yang menyenangkan maupun tidak menyenangkan.

b. Kemampuan untuk melibatkan diri atau menarik diri secara refleklif dari suatu emosi dengan mendasarkan pada pertimbangan adanya informasi atau kegunaan.

c. Kemampuan untuk memantau emosi secara reflektif dalam hubungan dengan diri sendiri dan orang lain, misalnya mengenal betapa jelas, khusus, berpengaruh, atau bemalar semuanya itu.

d. Kemampuan untuk mengelola emosi dalam diri sendiri dan orang lain dengan memadyakan emosi negatif dan memperbesar yang menyenangkan, tanpa menekan atau melebih-lebihkan informasi yang menyertainya.

Dengan demikian, mengelola emosi atau manajemen emosi menu rut teori di atas melibatkan kemampuan seseorang untuk mengendalikan ekspresi emosi negatif dan memperbesar ekspresi emosi positif bagi dirinya sendiri maupun orang lain. Mengelola emosi merupakan salah satu ketrampilan yang penting untuk mencapai kecerdasan emosional.

Manajemen emosi yang dimaksud dalam penelitian ini tidak diartikan dengan mengontrol emosi, melainkan lebih mengarah kepada kemampuan anak dalam mengontrol ekspresi emosi yang dirasakan. Anak dalam kondisi rawat inap, sebagai suatu kondisi yang menekan (stressor), mampu terbuka pada emosi-emosi yang dirasakannya dengan melakukan strategi dalam mengekspresikan emosinya itu. Inilah yang dimaksud dengan manajemen emosi. Ungkapan emosi yang diekspresikan merupakan ekspresi emosi yang benarbenar dirasakannya saat itu, bukan ekspresi emosi yang bersifat pura-pura (faking).

Setiap orang memiliki kemampuan yang bervariasi dalam mengontrol dan memanajemen ekspresi emosi. Planalp (1999) mengemukakan 2 cara yang dilakukan dalam mengontrol ekspresl emosi:

1. Surfiace acting

Surface acting merupakan manajemen ekspresi yang melibatkan aturan sosial (display rules) dan harapan sosial (social disorabilify). Misalnya seseorang dituntut untuk menampilkan suatu ekspres| emosi sedih ketika datang ke acara pemakaman, atau menampilkan ekspresi emosi senang ketika menghadiri pesta (Ekman \& Friesen, 1975).

\section{Deepacting}

Deep acting melibatkan aturan perasaan (fooling rules) yang tidak hanya berfungsl untuk menahan atau memunculkan emosi, tetapi jug a membentuk emosi yang sesuai dengan harapan sosial agar berakhir (Hochschild, 1983). Deep acting mengantarkan hubungan yang kompleks antara ekspresi emosi secara spontan dan strategis karena melibatkan manajemen emosi yang dirasakan spontan dengan cara yang strategis. Strategi dalam manajemen emosi ini dapat digunakan untuk manajemen emosi diri sendiri, emosi orang lain, maupun keduanya (Planalp, 1999).

Planalp (1999) mengemukakan tahapan manajemen emosi menggunakan strategi deop acting:

1. Manajemen peristiwa-peristiwa yang muncul (oliciting events)

2. Manajemen penghargaan (appraisal)

3. Manajemen reaksi fisiologis (physiological reactions)

4. Manajemen ekspresi dan impresi (expression and impression)

5. Melakukan strategi pendekatan sosial dan antisosial (social and antisocial)

Berdasarkan landasan teori di atas, penelitian ini mendefinisikan manajemen emosi sebagai kemampuan seorang anak untuk mengungkapkan, mengekspresikan, dan mengurangi emosi negatif yang muncul karena persepsi negatif individu terhadap kondisinya (negative perceived emotions). Diharapkan dengan berkurangnya Intensitas 
emosi negatif akan tercapai emosi positif dengan intensitas yang lebih besar melalui ekspresi tulis dan gambar.

\section{Faktor-faktor yang Mempengaruhi Manajemen Emosi padaAnak}

Menurut Hawadi (2001), masa kanak-Kanak awal yang dimulai saat masa bayl berakhir sampal usia 13 tahun merupakan masa yang penuh dengan persoalan bagi orang tua disebabkan anak sudah mulai ingin menunjukkan kebebasannya sebagal individu. Perkembangan emosi anak yang menonjol pada usia ini adalah mudahnya anak untuk ngambek maupun hal-hal lain yang bersifat emosi di mana pada akhirnya anak sulit untuk ditangani. Karakteristik emosional yang muncul lebih disebabkan faktor psikologis daripada faktor fisiologis. Hal ini didukung oleh pendapat Freud yang percaya bahwa kepribadian seorang anak yang sedang turnbuh dibentuk oieh dua kekuatan besar, pertama untuk mencari kesenangan, kedua untuk berusaha menghindari rasa sedih dan rasa tidak nyaman (Saphiro, 1997). Purwanto (1997) menambahkan bahwa banyak faktor intrapsikls yang mempengaruhi perbedaan perkembangan emosional, seperti persepsi, atensi, memori, kognisi, dan motivasi. Sedangkan faktor interpsikis yang mempengaruhi seperti pola asuh orangtua, lingkungan sekltar, dan komunitas yang lebih luas.

Psikoterapi tradisional menonjolkan kesadaran emosi sebagai wahana utama untuk mengubah hidup. Mengajari anak memahami dan mengkomunikasikan emosinya akan mempengaruhi banyak aspek dalam perkembangan dan keberhasilan hidup mereka. Sebaliknya, gagal mengajari anak memahami dan mengkomunikasikan emosinya dapat membuat anak-anak rentan terhadap konfikkonflik dengan orang lain. Untuk itu mengenail dan mengungkapkan emosi adalah bagian yang penting dalam komunikasi dan juga merupakan aspek vital dalam pengendalian emosi (Saphiro, 1997).

Berdasarkan teori yang dikemukakan di atas, dapat dirumuskan faktor-faktor yang mempengaruhi manajemen emosi pada anak, antara lain :

1. FaktorPsikologis

Faktor psikologis berkaitan dengan kondisi psikis seorang anak, termasuk di dalamnya adalah kognitif, afektif, dan konatif. Salah satu dasar dari kemampuan mengelola emosi adalah kemampuan berpikir realistik. Artinya, melihat realitas secara tepat sehingga anak depat menyesuaikannya dengan perilaku yang tepat pula. Pada umumnya, manusia dapat mengontrol emosinya dengan cara berpikir (Ayahbunda, 2002).

2. Faktor Fisiologis

Para ahli ilmu saraf kini percaya bahwa emosi dikirimkan dan dikendalikan melalui suatu sistem komunikasi secepat kilat dalam otak, yang didominasi oleh talamus, amlgdala, dan lobus frontal pada korteks, dengan dukungan berbagai struktur dan kelenjar otak lain yang mengirimkan informasi dalam bentuk biokimia ke seluruh bagian tubuh. Amigdala merupakan bagian otak yang bertugas mengelola emosi, sedangkan lobus frontal dalam korteks mempunyai peran khusus yang penting dalam pengendalian emosi (Saphiro, 1997).

3. Faktor Sosial

Faktor soslal berkaitan dengan pengajaran dan pola hidup sehat yang diterapkan dari lingkungan keluarga dasar pembentukan terciptanya perkembangan perilaku kesehatan. Pemberian fasilitas yang mampu mengoptimalkan anak agar sehat secara fisik, emosi, dan sosial juga menjadi faktor penting agar anak mampu melakukan manajemen emosi.

\section{Dinamika Psikologis Pasien Anak-anak yang Dirawat Inap}

Pengalaman menunjukkan bahwa anak-anak dari segala usia yang dirawat inap di rumah sakit mengalami distres. Namun sejalan dengan perkembangan usia, ada kecenderungan terjadi perubahan distres (Sarafino, 1986). Anak-anak yang terbiasa melakukan banyak aktivitas ketika sehat 
akan cenderung mengalami stres ketika dirawat inap. Mereka akan memprotes dan bersikap melawan ketika mendapatkan perlakuan medis yang menuntut mereka untuk mengurangi gerakan dan akitivitas (Smith \& Autman, 1985). Walaupun demikian, hal yang paling rentan menjadi sumber stres pada anak-anak yang dirawat inap adalah keterpisahan dari orang tua mereka (Sarafino, 1998).

Menurut Sarafino (1998), anak-anak pada usia sekolah memiliki kemampuan coping lebih baik dibandingkan dengan anak pra sekolah. Hal ini disebabkan kemampuan kognitif anak usia sekolah sudah mulai berkembang dengan baik. Anak usia sekolah cenderung lebih mudah mentoleransi keterpisahan dengan orang tua mereka. Namun demikian, konsep mereka mengenai mengapa mereka dirawat inap dianggap sebagai suatu hukuman yang harus mereka terima akan menetap selama masa kanakkanak awal mereka. Smith \& Autman (1985) mengemukakan empat aspek mengenai rawat inap yang tampaknya semakin sulit bagi anak-anak untuk menghadapi, antara lain:

1. Perasaan yang berkaitan dengan kontrol diri (personal controf). Sejalan dengan perkembangan usia mereka, maka semakin kompleks pula fungsi kognitif dan tuntutan sosial yang harus dipenuhi. Jika anak dirawat inap dalam jangka waktu yang lama sehingga kebebasannya menjadi terbatas, maka pengalaman dirawat inap akan membuat anak menjadi rentan dan mengalami distres.

2 Kemampuan kognitif yang semakin berkembang pada anak usia sekolah akan memunculkan pikiran dan kecemasan mengenal hasil atau akibat yang terjadi mengenai sakit dan tritmen yang merekajalani.

3. Jauh dari teman-teman bermain maupun teman sekolah akan memunculkan perasaan kesepian. kebosanan, dan pikiran bahwa mereka mungkin akan kehilangan teman atau status dalam kelompok sosial.

4. Saat mereka berada pada masa puber, ada kecenderungan untuk menjadi lebih pemalu mengekspresikan kondisi fisik mereka.

Anak anak dengan penyakit medis yang serius sehingga mereka harus dirawat inap sangat beresiko mengembangkan masalah-masalah emosional yang saling berhubungan satu sama lain (Facts for Families, 1999). Sarafino (1998) menjelaskan bahwa orang dari segala usia memiliki kesulitan dalam melakukan coping ketika mendapatkan perawatan inap dan perlakuan medis. Intervensi psikologis dapat membantu meningkatkan penyesuaian emosi positif antara pasien dan mengurangi masalah-masalah psikologis yang berhubungan dengan kondisi fisik / medis mereka.

Dengan demikian, dapat dikatakan bahwa anak-anak yang dirawat inap di rumah sakit memiliki kecenderungan mengalami tekanan-tekanan psikis yang akan mempengaruhi kondisi fisik mereka. Jika hal ini berlangsung lama dan menetap, maka anak mengalami suatu pengalaman yang bersifat traumatis dalam kehidupan kanakkanak mereka.

\section{Buku "Pelangi hatiku": Media Manajemen Emos! melalui Ekspresi Tulis dan Gambar} Pengambilan nama "Pelangi Hatiku" memiliki filosofi tersendiri. Kondisi sakit terutama ketika diharuskan istirahat di tempat tidur secara total (fotal bedrest) menyebabkan munculnya berbagai emosi seperti bosan, marah pada diri sendiri, takut, sedih, dan cemas. Emosi ini cenderung bersifat negatif dan mudah berubah-ubah. Emosi ini memiliki intensitas yang berbeda dan dapat berubah tiba-tiba hanya dalam beberapa menit. Kondisi ini kemudian akan mempengaruhi pikiran ketika sakit. Berbagai macam emosi yang muncul sangat bervariasi serta bersifat individual dan mewarnai suasana hati seseorang. Untuk itu digunakan nama "Pelangi Hatiku" sebagal gambaran emosi yang bervariasi.

Mengapa menulis dan menggambar? Berdasar pengalaman pribadi peneliti, menulis dan menggambar memiliki manfaat yang cukup besar. Peneliti mencoba 
menuliskan apa yang dirasakan dan menggambarkannya walau hanya berupa garis dan goresan-goresan abstrak. Setelah beberapa waktu, apa yang ditulis dan digambar dicoba untuk dilihat dan dibaca, ada banyak hal yang dapat dijadikan refleksi dan introspeksi untuk memperbaiki diri. Agar kondisi sakit dan rawat inap tidak dirasakan sebagai suatu pengalaman buruk, maka menulis dan menggambar merupakan aktivitas positif yang bermanfaat untuk refleksi dan introspeksi sehingga persepsi negatif seminimal mungkin muncul dalam kondisi sakit tersebut.

Dengan demikian, yang dimaksud dengan buku "Pelangi hatiku" yang digunakan dalam penelitian adalah media tulis dan gambar yang terdiri dari kertas wa rna-warni untuk menceritakan pengalaman atau peristiwa yang dialami serta emosi yang dirasakan.

Penelitian sejenis dengan menggunakan buku sebagai media ekspresi juga pernah dilakukan oleh Setyawati dkk (2000). Penelitian ini menggunakan buku yang diberi nama "Buku Cermin Emosi" sebagai sarana untuk meningkatkan ekspresi ide pada anak. Tujuan dari penelitian ini adalah untuk melihat efektivitas penggunaan "Buku Cermin Emosi" dalam meningkatkan kelancaran ekspresi ide pada anak. Karakteristik yang digunakan dalam "Buku Cermin Emosi" kemudian diadaptasi menjadi buku "Pelangi Hatiku" sebagai media manajemen emosi pada pasien anakanak.

\section{Metode Penelitian}

Subjek yang terlibat dalam penelitian ini adalah 3 (tiga) orang pasien anak-anak usia 8 tahun (subjek 1), 10 tahun (subjek 2), dan 12 tahun (subjek 3) yang dirawat inap di rumah sakit umum, yaitu 2 orang dirawat di Rumah Sakit Sardjito, dan 1 orang dirawat di Rumah SakitPKU Muhammadiyah.

Tabel 2.

Metode Pengumpulan Data

\begin{tabular}{|c|c|c|c|c|}
\hline No & Instrumen & Aspek yang dlungkap & Metode & Urutan \\
\hline 1 & Catatan kesehatan & $\begin{array}{l}\text { Riwayat penyakit ; } \\
\text { lama rawat inap }\end{array}$ & Rekam medis & 1 \\
\hline 2 & Angket Trauma & $\begin{array}{l}\text { Kecenderungan mengalami } \\
\text { trauma }\end{array}$ & Angket tertufis & 2 \\
\hline 3 & Wawancara Terstruktur & $\begin{array}{l}\text { Pengenalan dan pengelolaan } \\
\text { emosi }\end{array}$ & Wawancara & 3 \\
\hline 4 & Skala Deteksi Emosi & Pengelolaan emosi & Observasi & 3 \\
\hline 5 & Buku Pelangi Hatiku & $\begin{array}{l}\text { Kemampuan mengenal dan } \\
\text { mengelola emosi ; optimisme ; } \\
\text { emosi yang sering muncul }\end{array}$ & $\begin{array}{l}\text { Menulis dan } \\
\text { menggambar; } \\
\text { observasi; } \\
\text { umpan balik }\end{array}$ & 4 \\
\hline
\end{tabular}

\section{Hasii Penelitlan}

Temuan-temuan penelitian ini berdasarkan hasil pengumpulan data melalui wawancara terstruktur (WT), catatan lapangan (CL), dan Buku "Pelangi Hatiku" dari subjek 1, subjek2, dan subjek3.

Melalui penelitian ini ditemukan tahapan manajemen emosi yang dilakukan oleh sebagian besar pasien sebagai suatu bentuk coping emosional:

1. Mengekspresikan emosi

Dari penelitian ini ditemukan bahwa pada sebagian besar kasus muncul kemampuan untuk mengekspresikan emosi secara spontan. Seperti yang diungkapkan oleh subjek berikut: 
Sebelum terapi :

Sedih ketika merasakan sakit di tubunnya. Senang ketlka diperbolehkan pulang (Subjek 3, WT). Senang kalau ditinggal sendirian di kamar. Takut ketika akan diperiksa dokter atau perawat. (Subjek 1, WT).

Marah kalau ditinggal sendirian of kamar. Takut ketika diperiksa oleh dokteratau perawat (Subjek $2, W T$ ).

Sesudah terapi :

Takut ketika merasakan sakit di tubuhnya. Takut ketika harus kontrol ke rumah sakit (Subjek 3, WT).

Takut ketika ditinggal sendirian of. rumah padahat masith sakit. Blasa ketika diperiksa dokter atau perawat (Subjek 1, WT).

Biasa ketika ditinggal sendirian di rumah padahat masih sakif. Biasa ketika diperiksa oleh dokter atau perawat saat kontrof (Subjek 2, WT).

Emosi yang dirasakan subjek pada kasus di atas juga diekspresikan dalam bentuk non verbal melalui observasi yang dilakukan peneliti.

Sebelum terapi:

Kerutan ol sekitar mata terlihat jelas (Subjek 3, SDE).

Telapak kaki menegang agak jolas (Subjek 1, SDE).

Gerakan kedua bibir ke atas terlihat sangat jelas. Telapak kaki menegang terlinat jelas (Subjek 2, SDE).

Sesudah terapl:

Lengan bergerak ke depan terlihat jelas (Sub jek 3, SDE).

Gerakan kedua bibir ke bawah terlihat samar-samar. Lengan bergerak ke depan terlihat samar-samar. Lengan bergerak ke belakang terlihat samarsamar. Tumit bergerak-gerak terlihat samar-samar(SUb jek 1, SDE).

Apa yang diungkapkan oleh subjek sebelum terapi dan sesudah terapi pada kasus di atas dipengaruhi oleh suatu pengalaman sebelumnya yang dirasakan oleh subjek.
Pada itulah hatiku sedih saat merasa kesakitan perutku. Saat itu aku gellsah tidak bisa tidur dengan nyeyak. Ayah dan ibu juga tidak bisa tidur hanya memikirkan saya yang kesakitan. Pada malam hari sekitar pukul 22.00 itu saya kesakitan sekali orangtua bingung mencarl daun kates of kebun karena petang. Memang pada waktu itu saya sedih sekali. Saya minta orangtua saya membawa ke rumah sakit. Setelah ke rumah sakit saya diberi obat. Lalu setelah itu sudah sembuh lalu kambuh lagi (Subjek 3, $\mathrm{BPH}$ ).

Subjek menangis ketika akan disuntik. Subjek mengatakan tidak takut dengan dokter atau perawat, hanya takutjika disunfik, karena pernah pada saat dilnfus posisi suntikan salah dan subjek merasa kesakitan (Subjek 1 . CL).

... dan df rumah saya soring me non ton TV karsna pada waktu di rumah sakit saya tidak bisa menonton acara TV karena tidak ada TV. Kafau df rumah ada TV dan saya senang of rumah daripada di rumah sakit. Saya sekarang berada of rumah sakit dan sudah lama berada of rumah sakit aku bosan of rumah sakit rasanya ingin pulang.Aku di rumah sakit tiolak bisa tidur karna adek-adek yang kecil pada menangis keras sekali kama takut disuntik. Akhirnya aku menantikan hari yang kutunggu-tunggu yaitu hari aku maupufang (Subjek 2, BPH).

Pada kasus di atas nampak bahwa ekspresi emosi subjek pada peristiwa yang hampir sama akan direspon sesuai dengan pengalaman mereka. Ekspresi emosi yang ada tidak hanya muncul secara rasa, namun juga muncul secara fisik dan pikir.

2. Memikirkan peristiwa-peristiwa secara mendalam

Apa yang dialami subjek selama sakit dalam kondisi rawat inap pada umumnya direspon secara mendalam oleh subjek pada setiap Kasus. 
Sebelum terapi :

Sedih ketika merasakan sakit di tubuhnya. Senang kalau ditinggal sendirian di kamar (Subjek 1, WT).

Sedih ketika merasakan sakit di tubuhnya. Biasa kalau ditinggal sendirian di kamar (Subjek 3, WT).

Takut ketika merasakan sakit di tubuhnya. Marah ketika ditinggal sendirian di kamar (Subjek 2, WT).

Sesudah terapl:

Takut ketika merasakan sakit di tubuhnya. Takut ketika ditinggal sendirian di rumah padahal masih sakit(Subjek 1, WT).

Sedih ketika merasakan sakit di tubuhnya. Takut ketika ditinggal sendirian di rumah padahal masih sakit(Subjek 3, WT).

Takut ketika merasakan sakit di tubuhnya. Biasa ketika ditinggal sendirian di rumah padahal masith sakit(Subjek2, WT).

Pernyataan subjek pada kasus di atas diperkuat dengan pengamatan yang dilakukan ketika pernyataan di atas diberikan oleh subjek:

Sebeium terapi:

Kerutan di dahi samar-samar. Lengan bergerak ke depan samar-samar. Lengan bergerak ke belakang samar. samar. Tumit bergerak-gerak samarsamar(Subjek 1, SDE).

Kerutan di sekitar mata terlihat jelas. Gerakan bibir atas ke atas terlihat jelas. Tangan terangkat ke bahu terlihat agakjolas (Subjek 3, SDE).

Suara bergetar terdengar agak jelas (Subjek 2, SDE).

Sesudah terapi :

Gerakan kedua bibir ke bawah terlihat samar-samar. Telapak kaki menegang terlihat agak jelas (Subjek 1, SDE).

Lengan bergerak ke depan terlihat agakjelas (Subjek 3, SDE).

Gerakan kedua bibir ke atas terihat jelas. Tumit bergerak-gerak tertihat jolas (Subjek 2, SDE).

Kasus di atas juga didukung oleh latar belakang subjek. Seperti kasus berikut menggambarkan pengalaman sakit dan rawat inap pertama kali serta ketakutan yang muncul pada pasien jika penyakit yang dideritanya kambuh lagi.

Pada itulah hatiku sedih saat merasa kesakitan perutku. Saat itu aku gelisah tidak bisa tidur dengan nyeyak. Ayah dan ibu juga tidak bisa tidur hanya memikirkan saya yang kesakitan. Pada malam hari sekitar pukul 22.00 itu saya kesakitan sekali orangtua bingung mencari daun kales di kebun karena petang. Memang pada waktu itu saya sedih sekall. Saya minta orangtua saya membawa ke rumah sakit. Setelah ke rumah sakit saya diberi obat. Lalu setelah itu sudah sembuh lalu kambuh lagi. Lalu pada suatu hari ayah membawa ke rumah sakit besar of Klaten mau of komputer. Setelah dikomputer saya tidak tahu hasilnya, hanya orangtua yang tahu hasilnya. Saya disuruh keluar. Orangtua hanya bilang kalau akan dibawa ke rumah sakit Sarjito tempat dulu operasi. Hanya itu saja orangtua bilang, kan sedih tidak diberitau. Apa sih penyebabnya apa ada kelainan, mikir saya begitu. Sampai tanya orangtua tak diberitau. Kan saya sudah besar, sudah kelas enam kok tidak diberitahu penyakitnya yang sebenarnya (Subjek 3, BPH).

3. Melibatkan atau menarik diri secara refiektif dari suatu ernosi

Kondisi rawat inap yang dialami oleh subjek cenderung direspon sebagal sesuatu yang membosankan. Peristiwa yang direspon dengan emosi negatif terjadi pada kasus berikut:

Takut ketika ditinggal sendirian of rumah padahal masih sakit (Subyek 1, $(W T)$.

Sedih ketika merasakan sakit di tubuhnya (Subyek 3, WT).

Takut sebolum masuk rumah sakit. Takut ketika merasakan sakit dl tubuhnya. Sedih ketika tidak boleh makan makanan kesukaan oleh dokter. Ma rah kalau ditinggal sendirian of kamar(Subyek $2, W T$ ). 
Pada peristiwa yang direspon dengan emosi negatif, beberapa kasus menunjukkan adanya penarikan diri secara reflektif. Temuan di lapangan menunjukkan adanya perbedaan penarikan diri pada setiap kasus. Seperti pada kasus Subyek 1 yang cenderung menampakkan kebutuhan untuk diperhatikan oleh orang lain.

Subjek masih tidak mau ditinggal sendiri (Subyek 1, Cl).

Kelnginan subjek untuk ditemani di rumah karena belum sembuh ini ditunjukkan melalui gambar yang dibuat pada tanggal 7 Juli 2003, sehari sebelum kepulangannya dari rumah sakit.

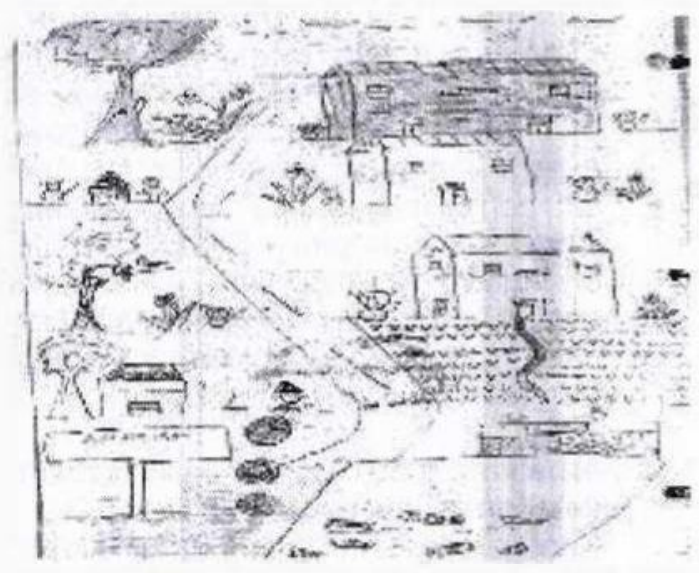

Gambar 1.

Keramalan lingkungan rumah

(Subyek 1, BPH)
Gambar 1. di atas menunjukkan keramaian di lingkungan rumah sebagai ekspresi emosi dari perasaan kesepian atau ditinggal sendiri di rumah. Sedangkan pada kasus Subyek 3 , subjek cenderung untuk menuliskan dan memberi nilai emosl terdalam yang dirasakannya saat itu. Mengarang Pahlawan

Pada waktu penjajahan dahulu banyak orang yang meninggal. Contohnya : .... Walaupun Indonesia diserang dengan senjata senapan indonesia tetap maju bersatu walaupun ada orang bangsanya menhggal. Indonesia tidak takut mati mempertahankan kemerdekaan. ...... Walaupun gugur mereka tidak bisa merasakan enak kemerdekaan ini. Biarkan pahlawan diterima di sisi Tuhan yang Maha Kuasa Amin (Subyek 3, BPH).

Nilai yang diberikan terhadap emos| negatif yang dirasakannya, yaitu duka, adalah 10. Ini menunjukkan emosi sedih yang dialami subjek sang at dalam saat itu.

Namun demikian, ada satu temuan menarik pada satu kasus yang melakukan keterlibatan diri pada emosi negatif yang dirasakannya.

Kolak 1. Keterlibatan diri yang mendalam pada emosi negatif

Subjek mengucilkan diri dari banyak orang dan menunjukkan tanda-tanda kehilangan kepercayaan Subjek merasa lapar, tapl menolak makanan yang diberikan dari rumah sakitNangis sejak kemarin karena nggak ada yang menjenguk (Subyek 2, CL). 
4. Memadyakan ekspresi emosi negatif dengan memperbesar ekspresi emosi positif

Pada pasien anak-anak yang harus menjalani pemeriksaan yang lebih mendalam dan detil (misalnya uji laboratorium), muncul adanya kecemasan terhadap jenis penya kit yang dideritanya.

Orangtua hanya bilang kalau akan dibawa ke rumah sakit Sarjito tempat dulu operasi. Hanya itu saja orangtua bilang, kan sedih tidak diberitau. Apa sih pernyebabrya apa ada kelainan, mikir saya begitu. Sampai tanya orangtua tak diberitau. Kan saya sudah besar, sudah kelas enam kok tidak diberitahu penyskitnya yang sebenamya (Subyek 3, BPH).

Bila kemudian diperlukan penanganan lebih lanjut, yaitu menjalani rawat inap, maka gangguan yang terjadi pada mekanisme keseimbangan dalam aktivitas kehldupan akan menjadi lebih besar. Besamya tekanan yang dihadapi akan sebanding dengan besarnya perubahan seacara psikis, sosial, dan psikologis yang menyertai perpindahan dari kehidupan rumah menuju ke Rumah sakit.

Ada tetangga baru di sebelah, sempat marah karena fan-nya dlpakai tetangga sebelah. Dia nggak mau makan makanan dari RS. Katanya gak suka dan gak enak baunya (Subyek 2, CL).

Dalam contoh yang dikemukakan di atas, perubahan tersebut menjadi stresor yang memunculkan emosi marah dalam proses penyesuaian subjek terhadap situasi baru. Secara sosial, perasaan terpisah dari teman-temannya dan tidak dapat melakukan aktivitas yang biasa dilakukannya membuat anak merasa kesepian, bosan, dan berpikiran bahwa mereka mungkin kehilangan teman.

... dan di rum ah saya sering me nonton TV karena pada waktu of rumah sakit saya tidak bisa menonton acara $T V$ karena tidak ada TV. Kalau df rumah ada TV dan saya senang of rumab daripada di rumah sakit. Saya sekarang berada of rumah sakit dan sudah lama berada of rumah sakit aku bosan of rumah sakit rasanya ingin pulang (Subyek 2, BPH).

Dari gambaran-gambaran di atas. tampak bahwa anak-anak tersebut telah memunculkan emosi-emosi negatif sehingga membutuhkan intervensi psikologis agar dapat mengelola respon emosionalnya.

\section{Pembahasan}

Ekspresi emosi yang muncul secara spontan dalam tulisan dan gambar yang dibuat merupakan suatu proses intrinsik yang melibatkan kognitif, afektif, dan fisik. Pasien yang merespon emosi sedih menjadi emosi takut ketika merasakan lagi sakit di tubuhnya disebabkan oleh pengalamanpengalaman yang muncul selama proses sakit diolah baik secara pikir, rasa, maupun fisik. Hal ini memunculkan perubahan reaksi emosi yang direspon dari peristiwa yang sama yang pemah dialami oleh pasien sebelumnya. Reaksi-reaksi emosi ini melibatkan strategi untuk mempertahankan. meningkatkan, mengontrol, dan atau menghambat emosi-emosi daiam usaha untuk mencapai tujuan (Denham, 1998).

Secara umum berdasarkan hasil temuan dalam penelitian ini, terdapal dua strategi dalam mengontrol ekspresi emosi yaitu surface acting dan deep acting. Deep acting merupakan usaha pencapaian tujuan secara spontan manajemen komunikasi secara strategis dan merasakan perasaan yang dinginkan secara spontan (Conrad \& White, 1994; Tice \& Baumeister, 1993). Planalp (1999) menyatakan bahwa strategi manajemen emosi dapat digunakan untuk memanaje emosi dalam diri sendiri, emosi orang lain, atau keduanya. Strategi deep acting berdasarkan temuan dalam penelitian ini masih dalam taraf manajemen emosi untuk diri sendiri. Manajemen emosi ini melalui empat penahapan yaitu mengekspresikan emosi, memikirkan peristiwa-peristiwa secara mendalam, melibatkan atau menarik diri secara reflektif dari suatu emosi, dan memadyakan ekspresi 
emosi negatif dengan memperbesar ekspresi emosi positif. Manajemen emosi dapat dilakukan melalul empat tahap, yaitu manajemen peristiwa-peristiwa yang muncul, manajemen pertimbangan akan nilai-nilai, manajemen ekspresi dan impresi, dan strategi sosial dan antisosial (Planalp. 1999).

Manajemen pada periștiwa-peristiwa yang muncul merupakan strategi yang dilakukan dari menghindari situasi sampai melakukan pengukuran yang nyata mengenai situasi tersebut. Hal Ini terjadi ketika pasien mengalami peristiwa yang menimbulkan reaksi emosi negatif pada kondisi sebelum dirawat inap sampai pada selesainya proses rawat inap. Kemudian reaksi emosi negatif ini diekspresikan baik dalam tulisan maupun gambar dengan menceritakan kembali peristlwa-peristiwa yang dialami kemudian diukur seçara nyata melalui perilaian emosi yang dirasakan ketika menulls dan menggambar.

Strategi yang kedua adalah melakukan manajemen pertimbangan akan nilai-nilai. Ekspresi emosi yang direaksi oleh pasien dalam suatu perilaku dilakukan dengan pertimbangan akan nilai-nilai sosial. Emosi sedih yang dirasakan tidak secara langsung direaksikan dalam bentuk perilaku menangis, namun pasien menuliskannya dalam bentuk pulsi yang memberi kesan sedih. Begitu juga dengan emosi ma rah yang dirasakan tidak diekspresikan dalam bentuk perilaku fantrumatau berteriak-teriak, namun diekspresikan melalui pengutaraan secara jujur secara tertulis ataupun gambar.

Manajemen ekspresi dan impresi merupakan pengontrolan terhadap emosi yang dirasakan dan yang diekspresikan. Seperti yang dilakukan pasien ketika muncul reaksi-reaksi emosi tertentu yang diekspresikan secara spontan dalam bentuk tulisan, gambar, maupun ekspresi wajah dan isyarat tubuh (gestures). Ketlka merasakan emosi sedih, pasien mengekspresikan melalul wajah dengan menampakkan kerutan di sekitar mata.

Strategi terakhir yang digunakan adalah strategi sosial dan antisosial. Emosi dapat dimanaje secara sosial dengan mencoba menciptakan suatu impresi atau perilaku tertentu "seandainya..." dengan harapan hal itu akan menjadi kenyataan. Pasien menggunakan strategi ini dengan harapan akan mempercepat kesembuhan. Dalam hal ini pasien menciptakan suatu kondisi atau situasi dengan mengekspresikan dalam gambar dan tulisan untuk mendapatkan suatu kondisi emosi yang lebih baik. Bahkan pasien Juga melakukan penciptaan perilaku dengan mengkondisikan situasi tertentu di rumah seperti ketika dia dirawat inap. Hal ini dilakukan dengan harapan akan segera sembuh dari sakitnya. Paslen melakukan analogi bahwa kondisi atau s|tuasi tertentu di rumah sakitsudah membuatnya sembuh dari rawat inap sehingga situasi tersebut diciptakan di rumah dengan harapan akan membuatnya sembuh dari sakitnya.

Selain itu, semakin sedikitnya gerakan, kerutan, dan nada pada bagian tubuh ketika seseorang dirawat inap menunjukkan semakin sedlkitnya reaks| emosi yang dialami pasien. Sebelum pemberian buku "Pelangi Hatiku" pasien memunculkan gerakan pada bagian tubuh yang samar-samar dan jelas, namun setelah pemberian buku "Pelangi Hatiku" gerakan pada bagian tubuh hampir tidak ada. Dapat diartikan bahwa makln sedikit nilai yang diperoleh makin mampu pasien mengelola suasana hatinya (Prawitasari, 2000).

Meskipun demlkian, dalam penelitlan ini juga dltemukan bahwa tidak semua paslen melakukan keempat strategi deep acting untuk manajemen emosi, yaitu tidak dilakukannya strategi manajemen ekspresi dan impresi. Hal ini disebabkan faktor latar belakang pasien, terutama keluarga, yang mempengaruhl identifikasi emosinya. Temuan ini sejalan dengan pendapat Fuendellng (1998) yang menyatakan bahwa anak-anak yang melakukan penolakan mengalami emosi negatif yang berhubungan dengan penolakan, sebagai konsekuenslnya mereka belajar untuk menonaktifkan ekspresi dari perasaan negatifnya dengan menolak jalinan hubungan dekat, yang kemudian menghilangkan dan membutakan semua 
pengalaman afeksinya. Dalam interaksi dengan anak, model ekspresi emosi orangtua (Gamer dkk, 1997) sejalan dengan teknik pengaturan emosi yang dilakukan anak-anak (Denham, 1998).

\section{Kesimpulan Dan Saran}

Kesimpulan yang disampaikan adalah manajemen emosi yang dilakukan anak melalui buku "Pelangi Hatiku" memiliki empat tahapan, yaitu mengekspresikan emosi secara spontan, memikirkan peristiwaperistiwa secara mendalam, melibatkan atau menarik diri secara reflektif dari suatu emosi, dan memadyakan ekspresi emosi negatif dengan memperbesar ekspresi emosi positif. Penurunan skor Skala Deteksi Emosi saat pretes dan postes menunjukkan bahwa ada peningkatan kemampuan manajemen emosi pada pasien anak-anak setelah diberikan buku "Pelangi Hatiku".

Selanjutnya, peneliti memberikan saran untuk orangtua dan peneliti selanjutnya:

1. Medical Staff dan orangtua

a. Ekspresi menulis dan menggambar menggunakan buku "Pelangi Hatiku" dapat juga digunakan sebagai media pengenalan dan pengelolaan emosi pada anak dan dapat digunakan sebagai terapi pendamping dalam terapi medis yang dilakukan di rumah sakit ketika anak rawat inap atau ketika anak menderita sakit.

b. Diharapkan orangtua juga mampu berkomunikasi dengan anak melalui buku "Pelangi Hatiku" dan lebih peka terhadap emosi yang dirasakan anak sehingga tidak menuntut suatu ekspresi emosi yang tidak sesuai dengan yang dirasakan anak.

2. Peneliti selanjutnya

Penelitian ini adalah penelitian kualitatif yang dilakukan pada pasien anakanak yang dirawat inap di rumah sakit. Oleh karena kemajuan penelitian sangat tergantung pada kondis| kesehatan, kesiapan, dan kemampuan anak, maka perlu dipertimbangkan lagi lamanya penelitian yang akan dilakukan, domisili pasien dan keluarganya, serta lamanya pemberian buku "Pelangi Hatiku".

\section{KEPUSTAKAAN}

Ayahbunda. 2002. Artikel : Mengontrol Emosi.Majalah. Nomor 19/21 September 5 Oktober 2002. Jakarta: PT Grafika Multi Warna.

Campbell, L, Campbell, B., \& Dickinson, D. 1996. Teaching and Leaming Through Muttiple Intelligences. Masachusetts : Alyn \& Bacon, Inc.

Conrad, C., \& Witte, K 1994. Is Emotional Expression Repression Oppression ? Myths of Organizational Effective Regulation. Dalam S.A. Deetz (Ed.), Communication Yearbook 17 (hal. 417-428). Califomia : Sage.

Denham, S.A. 1998. Emotional Development in Young Children. New York : Guildford Press.

Fuendeling, J.M. 1998.Affect Regulation as a Stylistic Process within Adult Altachment Journal of Social and Personal Relationship, 15 (3), 291 322.

Gamer, P.W., Robertson, S., \& Smith, G. 1997. Preschool Children's Emotional Expressions with Peers : The Roles of Gender and Emotion Socialization. Sex Roles, 36(11, 12), 675-691.

Glaser, R., \& Kiecolt-Glaser, J.K. 1994. Handbook of Human Stress and Immunity. San Diego : Academic Press.

Hurlock, E 1978. Perkembangan Anak Jilio 1. Edisi keenam. Jakarta : Penerbit Erlangga.

Laporan INSKA. 2002. Laporan Tahunan Instalasi Kesehatan Anak RS. DR. Sardjito Tahun 2002. TIdak 
Diterbitkan. Yogyakarta : Rumah Sakit Umum Pusat DR. Sardjito.

Lazarus, R.S. 1991. Emotion and Adaptation. New York: Oxford University Press.

Mason, J.W., Sachar, E.J., Fishman, J.R., Hamburg, D.A., \& Handlon, J.H. 1965. Corticosteroid Responses to Hospital Admission. Archives of General Psychiatsy, 13, 1-8.

Miles dan Huberman. 1992. Analisa Data Kualitatif: Buku Sumber tentang Metode-metode Baru. Terjemahan: Rohidi. Jakarta: Penerbit Universitas Indonesia.

Moos, R.H. 1977. Coping with Physical IIIness. New York: Plenum.

Parker, J., \& Asher, S. 1993. Friendship and Friendship Quality in Middle Childhood : Links with Peer Group Acceptance and Feelings of Loneliness and Social Dissatisfaction. Developmental Psychology. 29 (4), 611-621.

Pennebaker, JW. 1990. Ketka Diam Bukan Emas : Berbicara dan Menulis Sebagai Terapi (terjemahan). Bandung: PenerbitMizan.

Planalp, S. 1999. Communicating Emotion: Social, Moral, and Cultural Processes. Cambridge : Cambridge University Press.

Prawitasari, J.E. 2000. Pengembangan Metode Deteksi Emosi pada Pasien Rumah Sakit Umum. Laporan Penelitian. Tidak Diterbitkan. Yogyakarta : Fakultas Psikologi Universitas Gadjah Mada.

Rekam Med is. 2003. Rekam Medis Tanggal 6 Januari 2003. Tidak Diterbitkan. Yogyakarta : Rumah Sakit Umum Pusat DR. Sardjito.

Sarafino. 1998. Health Psychology :
Biopsyhosocial Interactions. $3^{\text {ro }}$ edition. New York: John Wiley \& Sons, Inc.

Siegel, L.J., \& Hudson, B.O. 1992. Hospitalization and Medical Care of Children. Dalam Walker, C.E. \& Roberts, M.C. (eds). Handbook of Clinical Child Psychology. New York: John Wiley \& Sons.

Smith, J.B. \& Autman, S.H. 1985. The Experience of Hospitalization. Dalam L.L. Hayman \& E.M. Sporing (Eds.), Handbook of Pediatric Nursing. New York: Wiley.

Taylor, S.E. 1995. Health Psychology. New York: McGraw-Hill, Inc.

Taylor, S.E., \& Aspinwall, L.G. 1990. Psychological Aspects of Chronic filness. Dalam G.R. VandenBos \& P.T. Costa, jr. (eds). Psychological Aspects of Serious lliness. Washongton, D.C : American Psychological Association.

Tice, D.M., \& Baumeister, R.F. 1993. Controlling Anger : Self-induced Emotion Change. Dalarn D.M.Wegner \& J.W.Pennebaker (Eds.), Handbook of Mental Control (hal. 393-409). New Jersey: Prentice-Hall.

Ummi. 1999. Artikel : Cerita, Dongeng, \& Menggambar. Majalah. Edisi 9/X/99. Jakarta : PT Dian Rakyat.

Utami. D.S., \& Kumara, A 2003. Ekspresi Tulis dan Gambar sebagai Media Terapi. Jumal Psikologi. Yogyakarta: Fakultas Psikologi Universitas Gadjah Mada.

Williamson, G.M., Walters, A.S., \& Shaffer, D.R. 2002. Caregiver Models of Self and Others, Coping, and Depression : Predictors of Depression in Children with Chronic Pain. Health Psychology, Vol.21, No.4, 405-410. 